DOI https://doi.org/10.30525/978-9934-588-91-4-31

\title{
ЗМІНА МОДЕЛІ ДЕРЖАВНОЇ СЛУЖБИ ПОЛЬЩІ ПІСЛЯ ПРИЙНЯТТЯ ЗАКОНУ ПРО ДЕРЖАВНУ СЛУЖБУ В 2015 РОЦІ
}

\author{
Бровко О. В. \\ кандидат політичних наук, \\ викладач кафедри філософії та політології та політології \\ Харківського начіонального економічного університету \\ імені Семена Кузнеия \\ м. Харків, Україна
}

Актуальність теми дослідження. Сучасна Україна знаходиться на етапі реалізації євроінтеграційної стратегії. При цьому метою української держави є вирішення двох взаємопов'язаних завдань, 3 одного боку інтеграція у європейський політичний та соціально-економічний простір, а з іншого - розбудова ефективної моделі публічної влади на загальнодержавному i регіональному рівнях. Зазначена перспектива потребує ретельного вивчення шляхів наближення діючої моделі державної служби до європейських принципів і стандартів з врахуванням політикоадміністративних і соціально-економічних особливостей України.

Сьогодні державна служба реформується тільки епізодично, що не дає можливість підвищити ії ефективність та дієвість. Для проведення комплексної реформи необхідно врахувати власні потреби та пріоритети та зарубіжний досвід модернізації державної служби, зокрема Польщі, яка $є$ сусідньою країною, має схожий державний устрій та знаходиться в пошуку оптимальної моделі публічного адміністрування.

Аналіз останніх досліджень і публікацій. Питання організації та функціонування державної служби в Польщі досліджується вітчизняними науковцями: M.I. Лахижою, Х.М. Дейнегою, I.В. Поліщук, А.О. Чаркіною, С.П. Грибоножком.

Серед польських науковців, які вивчають особливості організації державної служби в Польщі варто виокремити: I. Ітріх-Драбарек. А. Міхалак, С. Сокальську, А. Лукащук, С. Мазура.

Але все таки державна служба Польща недостатньо досліджена, особливо вплив останніх законодавчих змін на їі функціонування.

Мета дослідження полягає у дослідженні впливу прийняття закону про державну службу в 2015 році на функціонування державної служби в Польщі.

323 січня 2016 року вступив в силу Закон від 30 грудня 2015 року про внесення змін до Закону про державну службу Польщі та деяких інших актів. Він суттєво вплинув на правила функціонування державної служби в Польщі. Основні зміни до закону про державну службу, 
прийняті Законом від 30 грудня 2015 року полягають у зміні принципу найму на керівні посади державної служби - відмова від принципу відкритості та конкуренції найму, замість якого було запроваджено працевлаштування на підставі призначення. Більше того, змінилися умови призначення керівника державної служби. Згідно з новими правилами, керівник державної служби до моменту початку трудових відносин на даній посаді не повинен бути державним службовцем, а також не повинен мати досвід роботи на керівних посадах. Його призначає та звільняє Прем'єр-міністр у будь-який час без попередньої консультації з будь-яким дорадчим органом [1].

Відповідно до положень Закону від 30 грудня 2015 року про внесення змін до Закон державної служби, Рада державної служби також була скасована, а на ії місці була створена Рада публічної служби, яка частково позбавлена попередніх повноважень Рада державної служби. Більше того, вона складається виключно з членів, яких призначає та звільняє Прем'єр-міністр.

У положенні ст. 153 п. 1 Конституції встановлено умови експлуатації корпус державної служби в офісах державної адміністрації; він повинен функціонувати з метою забезпечення професійного, надійного, неупередженого та політично нейтрального виконання державних завдань. Однакові умови експлуатації державна служба визначена у ст. 1 Закону про державну службу. Реалізація цих принципів стосовно працівників державної служби існували, серед іншого, від забезпечення чітких та об'єктивних критеріїв набору на державну службу та просування по службі. Попередні положення Закону про державну службу передбачали, що кожен громадянин має право на інформацію про вакансії на державній службі, а набір на державну службу є відкритим та конкурентоспроможним.

У літературі вказується про відкритість відбору, як це передбачено ст. 54 пункт 1 Закону про державну службу до внесення змін означала його універсальність, відкритість та рівність при поданні заяв на працевлаштування на вищу посаду на державній службі [2, с. 35]. Однак конкурентоспроможність найму означала процедуру, внаслідок якої повинен бути обраний кандидат на керівну посаду державної служби, що володіє знаннями, вміннями та іншими якостями, які $є$ найбільш відповідними серед усіх кандидатів, поданих на посаду, на яку шукають працівника [3, с. 64]

Тим часом, відповідно до змісту зміненого ст. 6 Закону про державну службу кожен громадянин має право на інформацію про вакансії на державній службі, а набір на державну службу є відкритим та конкурентоспроможним, 3 урахуванням положень глави 4 , яка застосовується до працевлаштування на керівні посади державної служби. Це означає, 
що законодавець виключив право громадян на інформування про вакантні керівні посади у цивільній службі.

Після внесення змін до Закону набір на державну службу людей, зайнятих на керівних посадах більше не відбувається на відкритій основі та конкурентоспроможності, а на основі довільного призначення, що суперечить правилам, передбаченим ст. 60 Конституції Республіки Польща, як права громадян доступу до державної служби на рівних умовах.

Як зазначає Губерт Іздебський у своєму висновку щодо акту, що вносить зміни до закону про державну службу, запровадивши призначення як основу для працевлаштування, водночас запровадження додаткового спрощення зайнятості безпосередньо політизуватиме управлінський сегмент державної служби [4]. Введення призначень як основи для працевлаштування на вищі посади державної служби було додатково пов'язане із скасуванням більшість вимог щодо вступу на керівні посади державної служби. Кандидати на керівні посади державної служби більше не повинні мати не менше шести років досвіду роботи, включаючи не менше трьох років досвіду роботи на керівній посаді в підрозділах сектору державних фінансів (у разі подання заявки на посаду генерального директора офісу) та не менше трьох років досвіду роботи, включаючи принаймні один рік на керівній посаді або дворічний на незалежній посаді в підрозділах фінансового сектору публічний (у разі подання заявки на інші вищі посади). Кандидати на керівні посади державної служби повинні мати лише вищу освіту, мати досвід управлінської діяльності та бути несудимими.

Поправки до Закону про державну службу ведуть до скорочення гарантій стабільності роботи, зниження кваліфікації, необхідної для початку роботи на державній службі, та обмеження об'єктивних критеріїв встановлення трудових відносин. Ці негативні зміни незабаром можуть призвести до значного зниження стандартів виконання завдань, покладених на державну службу Польщі. У довгостроковій перспективі це може спричинити зменшення повноваження та значення адміністрації як одного із суб'єктів реалізації основної функції держави щодо громадян.

\section{Література:}

1. Ustawa z 30 grudnia 2015 r. o zmianie ustawy o służbie cywilnej URL: http://isap.sejm.gov.pl/isap.nsf/download.xsp/WDU20160000034/O/ D20160034.pdf (дата звернення: 26.10.2020).

2. K. W. Baran Prawo urzędnicze - Komentarz, Warszawa 2014. 936 c. 
3. W. Drobny Ustawa o służbie cywilnej. Komentarz, Warszawa 2012. $808 \mathrm{c}$.

4. Opinia prawna prof. Huberta Izdebskiego z 3 lutego $2016 \mathrm{w}$ przedmiocie ustawy z dnia30 grudnia 2015 r. o zmianie Ustawy o służbie cywilnej oraz niektórych innych ustaw. URL: https://www.batory.org.pl/ upload/files/Programy\%20operacyjne/Odpowiedzialne\%20Panstwo/Opinia Sluzba_cywilna_HIzdebski.pdf (дата звернення: 26.10.2020).

DOI https://doi.org/10.30525/978-9934-588-91-4-32

ОСОБЛИВОСТІ МОДЕЛІ ПАРЛАМЕНТСЬКО-ПРЕЗИДЕНТСЬКОЇ РЕСПУБЛІКИ НА СУЧАСНОМУ ЕТАПІ РОЗВИТКУ УКРАЇНСЬКОЇ ДЕРЖАВНОСТІ

\author{
Вагіна О. М. \\ кандидат історичних наук, \\ доиент кафедри політологї \\ Запорізького національного університету \\ м. Запоріжжя, Україна \\ Комар А. Г. \\ студент III курсу юридичного факультету \\ Запорізького національного університету \\ м. Запоріжжя, Украӥна
}

Після революційних подій 2014 р. змішана модель правління в Україні вкотре зазнала конституційного реформування: відбулась трансформація із президентсько-парламентської республіки, що характеризувалась надмірною концентрацією влади в руках Президента України, у парламентсько-президентську, яку пов'язують із визначальною роллю парламенту, зокрема, у формуванні уряду. Актуальність дослідження феномену парламентсько-президентської республіки, яка наразі сформувалась в Україні, обумовлена, з одного боку, невідповідністю між теоретично визначеною формою і практичним змістовим наповненням чинної моделі державного правління, а з іншого - відсутністю їі усталеної термінологічної визначеності. Результати виборчих кампаній 2019 р. внесли суттєві корективи в розстановку політичних сил у країні та змінили внутрішній зміст форми державного правління за відсутності змін конституційноправової бази функціонування держави. Отже, своєрідна автентична 